\title{
Dagens sykehuslege - fremdeles alltid på vakt
}

\begin{abstract}
BAKGRUNN Norske sykehusleger fremholder verdien av å jobbe hardt og effektivt og ha stor grad av tilstedeværelse på jobb. Dette bidrar til å skape sosiale normer som virker styrende for atferd innen profesjonskulturen. Det er viktig å undersøke hvilke konsekvenser disse verdiene kan få, når legen også skal ivareta egne behov.
\end{abstract}

MATERIALE OG METODE Vi gjennomførte åtte fokusgruppeintervjuer og tre individuelle intervjuer blant til sammen 48 overleger og leger under spesialisering, som jobbet innen kirurgi, psykiatri og indremedisin ved to ulike sykehus. Totalt $\mathrm{N}=48,56 \%$ kvinner. Intervjuene ble analysert med systematisk tekstkondensering.

RESULTATER Når norske sykehusleger ønsker å fremstå som gode leger, opplever de at det får konsekvenser for samspillet med legekollegiet, ledelsen og balansen mellom hjem og jobb. Interessekonflikter fremkom mellom overleger og leger i spesialisering. Ledelsesinitiativ for å håndtere fravær, livsfasetilpasning av legejobben og økt lederengasjement blant leger var tiltak som ble foreslått.

FORTOLKNING Bedre gjensidig kunnskap mellom leger og ledelse om hverandres verdier og ansvarsområder vil være viktige premisser for å kunne gjøre strukturelle endringer, for eksempel bedre planlegging av fravær og mulighet for livsfasetilpasning i arbeidsplaner.

For å lære, utøve og oppdatere seg i faget, både teoretisk og håndverksmessig, kreves det ifølge legene vilje til høy grad av tilstedeværelse på jobb og stor arbeidskapasitet (1). Dette har vi i en tidligere artikkel kalt «faglig dedikasjon» (1). At legene viser faglig dedikasjon, og dermed spesielt tilpasser seg jobben, kan få konsekvenser for andre arenaer i livet. Flere studier har vist at balansen mellom hjem og jobb er krevende (2), samtidig som leger er sykmeldte i mindre grad enn andre med samme utdanningsbakgrunn og med samme diagnoser $(3,4)$. Det sterke kollegiale samholdet $\mathrm{i}$ den medisinske profesjonskulturen (5) kan gjøre leger mer motstandsdyktige mot stress (6) og øke jobbtilfredsheten (7). Men ønsket om tilhørighet til «legelauget» kan også føre til et press på legene om å innordne seg rådende kollegiale normer (8). For eksempel blir det ansett som uprofesjonelt av leger å kritisere hverandre (5). Det mangler gode beskrivelser av hvordan legenes yrkeskultur påvirker disse forholdene (9).

Det er mye søkelys i mediene på forholdet mellom sykehusledelse og leger (10), og avstanden mellom disse partene fremstilles gjerne som stor. Dedikasjonen til faget kan være en av grunnene til at legene ofte føler sterkere tilknytning til fag enn organisasjon (11), og det kan gjøre det vanskelig for sykehusledelsen å lede leger (12). På den annen side er ledelse og administrasjon en del av så å si alle legers hverdag, og ca. $60 \%$ av lederstillingene ved norske sykehus er besatt av leger (13). Ledelse som fag har tradisjonelt vært en liten del av legeutdanningen i Norge (14), og den sterke kliniske posisjonen legene har, kan stå i kontrast til maktesløshet i forhold til administrativt arbeid (15). Det blir derfor viktig å se nærmere på hvordan legene synes dette påvirker deres profesjonsutøvelse.

Vi vil her undersøke hvilke konsekvenser norske sykehusleger opplever at «faglig dedikasjon» får $\mathrm{i}$ arbeidshverdagen og for balansen mellom jobb og hjem.

\section{Materiale og metode}

Data ble samlet inn i perioden 2010-2012 gjennom åtte fokusgruppeintervjuer og tre individuelle intervjuer med til sammen 48 sykehusleger som hadde mellom 5 og 45 års erfaring som lege. 22 var leger i spesialisering og 26 overleger, i psykiatri $(\mathrm{n}=19$, $58 \%$ kvinner $)$, indremedisinske fag $(\mathrm{n}=15$, $40 \%$ kvinner $)$ og kirurgiske fag $(n=14$, $71 \%$ kvinner).

Via tillitsvalgte, ledere eller legemøteansvarlige informerte vi om studien. $\mathrm{Vi}$ rekrutterte et strategisk utvalg av overleger og leger i spesialisering i ett stort og ett mindre sykehus. I medisin og kirurgi intervjuet vi grupper med henholdsvis overleger og leger i spesialisering, og fordi det viste seg å være svært utfordrende å samle travle sykehusleger til gruppeintervju gjennomførte vi tre individuelle intervjuer med deltagere som ikke kunne møte i fokusgruppene. To gruppeintervjuer med psykiatere ble lagt til interne legemøter, og $\mathrm{i}$ begge gruppene deltok det både overleger og leger i spesialisering. Intervjuene varte $1-1,5$ timer og ble ledet av en moderator og én eller to medhjelpere (Tuva Kolstad Hertzberg, Karin Isaksson Rø og Olaf Gjerløw Aasland). Innledningsvis inviterte moderator til samtale: «Hvordan få til en god balanse i livet som

\section{Tuva Kolstad Hertzberg}

t.k.hertzberg@medisin.uio.no

Forskningsinstituttet Modum Bad

Vikersund

og

Avdeling for medisinsk atferdsvitenskap

Institutt for medisinske basalfag

Det medisinske fakultet

Universitetet i Oslo

\section{Helge Skirbekk}

Lovisenberg diakonale høgskole

Oslo

\section{Reidar Tyssen}

Avdeling for medisinsk atferdsvitenskap

Institutt for medisinske basalfag

Det medisinske fakultet

Universitetet i Oslo

\section{Olaf Gjerløw Aasland}

LEFO - Legeforskningsinstituttet

Oslo

\section{Karin Isaksson Rø}

LEFO - Legeforskningsinstituttet Oslo

og

Forskningsinstituttet Modum Bad

Vikersund

1D Engelsk oversettelse på www.tidsskriftet.no

\section{HOVEDBUDSKAP}

Fravær fra jobb kan se ut til å true idealet om den faglig dedikerte legens utholdenhet og arbeidskapasitet

Flere sykehusleger ga uttrykk for et ambivalent forhold til det å lede selv og å bli ledet

Synet på legeyrket som en livsstil versus en jobb skapte interessekonflikt mellom yngre og eldre sykehusleger

Den tradisjonelle oppfatningen av hva som er nødvendig grad av dedikasjon for en «god lege» er ikke klar 
sykehuslege?» - med konsekvenser og forslag til tiltak.

Analysemetoden var systematisk tekstkondensering, basert på Giorgio og utviklet og modifisert av Malterud (16). To av intervjuene ble kategorikodet av Tuva Kolstad Hertzberg og Karin Isaksson Rø, som deretter diskuterte kodingen sammen med Helge Skirbekk. Tuva Kolstad Hertzberg kodet så resterende intervjuer i henhold til dette. I en tidligere analyse av materialet rapporterte vi hvordan leger beskriver ønsker om å være og å fremstå som en god lege (1). Vi så da at dette hadde betydelige konsekvenser for legenes hverdag. For å undersøke disse konsekvensene ble dataene på ny analysert med dette som overordnet tema. Til slutt rekontekstualiserte vi resultatene mot datamaterialet for å finne likheter som styrket resultatene våre, og ulikheter som svekket dem (17). Dimensjonene som definerte det overordnede temaet, presenteres i resultatdelen som tekstoppsummeringer, med noen illustrerende sitater. Deltagerne i studien fikk tilbud om å lese gjennom resultatdelen for å godkjenne sitatene som brukes.

Fire av forfatterne er leger, med bakgrunn fra psykiatri/arbeidsmedisin og legekårsforskning. En av forfatterne er sosiolog med spesiell interesse for kommunikasjons- og tillitsforhold i helsetjenesten. Den enkelte forfatters bevissthet og nysgjerrighet om temaet, egne jobberfaringer og/eller erfaring fra klinisk arbeid med leger som har søkt rådgivning eller behandling, preget nok vår forståelse rundt typen utfordringer vi kom til å finne. Fordi forfattergruppen også representerer leger, både klinikere og forskere $\mathrm{i}$ ulike stadier av sin karriere, og en sosiolog, har vi kunnet gjenkjenne ulike aspekter ved temaet og dermed nærmet oss stoffet fra flere vinkler.

Undersøkelsen har godkjenning fra Regional komité for medisinsk og helsefaglig forskningsetikk.

\section{Resultater}

Konsekvenser knyttet til ønsket om å være en tilstedeværende, faglig dedikert lege med stor arbeidskapasitet kunne, basert på tekstanalysen, plasseres i tre dimensjoner: forholdet til legekollegiet, å lede og bli ledet og balansen mellom hjem og jobb. Enkelte forslag til tiltak ble også diskutert. Det fremkom få forskjeller mellom kjønn, spesialiteter og sykehus i forhold til disse dimensjonene.

\section{Legekollegiet}

Fordi mye tilstedeværelse på jobb og stor arbeidskapasitet ble ansett som viktige kjennetegn hos en god lege, ble den enkelte leges fravær i flere tilfeller fremstilt og opplevd som en mangel på lojalitet overfor kollegiet. Dette kan ses i lys av den ekstra belastningen kollegiet må bære ved slike anledninger. Flere av overlegene fremhevet sitt sjeldne fravær - én hevdet å ikke ha vært borte fra jobb på 35 år. De fleste intervjuede legene mente fravær i forbindelse med sykdom handlet mest om hvordan den enkelte lege taklet det å være syk. Ifølge noen leger i spesialisering kom det an på den enkelte leges styrke eller vilje til å ta seg sammen og gå på jobb på tross av sykdom. Fravær fra helgevakt krevde en spesielt god grunn for å være fraværende. En lege som var under spesialisering sa:

«Her er det sånn at hva som skal til for å være syk varierer litt. Har jeg helgevakt, helligdagsvakt eller sånt noe, ja, da er jeg i praksis ikke syk.» (Gruppe 8)

Flere leger under spesialisering sa at $\mathrm{i}$ jobben som lege «kan (man) ikke være syk». Konsekvensene av kollegers fravær var mer hektiske dager og mindre tid til faglig utvikling for de som var igjen på jobb, i tillegg til vakante vakter, noe som medførte mindre restitusjonstid. Fraværende leger i spesialisering skapte merarbeid og uforutsigbarhet også for overleger med driftsansvar. Både leger i spesialisering og overleger mente at sykehusenes marginale bemanningssituasjon gjorde avdelingene svært sårbare for fravær. Forventningen om ikke-fravær gjorde at enkelte leger i spesialisering ikke våget å dele sine personlige utfordringer med kolleger. En overlege omtalte det å si ifra om egne behov som «sutring». De legene med fravær som kollegene ikke opplevde som syke nok, kunne bli uglesett og oppfattet som ikke dedikerte eller sterke nok. Fravær på grunn av kurs eller annen faglig aktivitet ble derimot ansett som akseptabelt. Flere leger i spesialisering opplevde at det ikke ble akseptert å ta pauser eller spise lunsj, og de internaliserte dette i så stor grad at de undertrykte basale behov:

«... det er en opphopning av mennesker som glemmer å spise og tisse, det er et press. Når du ser og har sånne kolleger rundt deg, så er du en del av det. Enten så er du en del av det eller så er du utenfor.» (Gruppe 7)

\section{$\AA$ lede og bli ledet}

Flere overleger som var i lederstillinger sa at de kombinerte lederarbeid med klinisk arbeid for ikke å miste kontakten med faget, men også fordi det var faget de opplevde å være utdannet i, og ikke ledelse. Det var flere av disse som sa at de ikke ønsket å ta lederstillinger, men som opplevde at de var forpliktet til det. Det var en utbredt oppfatning at ledere med god klinisk innsikt og erfaring var de som fikk tillit og legitimitet fra de andre i legekollegiet, men at den doble rollen tok mye tid og kapasitet for dem det gjaldt. En overlege beskrev lederjobben som en identitetskrise:
«... jeg følte at jeg fikk nesten sånn identitetsforstyrrelse, sånn identitetskrise. Selv om jeg har det like travelt sånn arbeidstidsmessig som kliniker og doktor nå, som jeg hadde da (som leder), så er det på en annen måte. Nå gjør jeg det som jeg alltid har villet gjøre, og det er det jeg har tatt utdannelse for.» (Gruppe 2)

De legene som var ledere, ble av flere beskrevet som «en av dem», altså ledelsen, fordi disse ikke bare fokuserte på det faglige. Når legene i studien snakket om «ledelsen», var det ofte uklart hvilket nivå i ledelsen de siktet til. Flere, spesielt overleger, opplevde en avmakt overfor ledelsens manglende anerkjennelse av deres kompetanse og arbeidsinnsats, og flere ga uttrykk for at ledelsen i større grad burde tale legenes sak. De opplevde ledelsen som mer opptatt av system enn person, og mente ledelsen i for stor grad lot økonomi og produksjonskrav bestemme.

Både overleger og leger i spesialisering beskrev administrative oppgaver som noe som kom i tillegg til, og ofte konkurrerte med, de kliniske oppgavene. Samtidig mente flere at det var for få leger i administrative stillinger, og at dette kan utfordre både faget og den fremtidige legerollen.

\section{Balansen mellom arbeid og familie/egentid} De fleste legene var tilfreds med å være lege, men opplevde jobben som krevende å kombinere med fritid og familieliv. En overlege sa:

«Jeg blir ikke regnet med hjemme, og de er veldig lei av at jeg aldri kommer hjem. (...) 'Det er ikke vits i å lage middag til hele familien, fordi mamma (legen) kommer ikke hjem likevel'. Så de har innrettet seg etter det, og de venter ikke på meg lenger.» (Gruppe 6)

For å klare kombinasjonen av jobben som dedikert sykehuslege, et aktivt treningsliv som mange opplevde som nødvendig for stressmestring - og et fullverdig familieliv, fortalte både overleger og leger i spesialisering at de var helt avhengige av støtte fra partner og/eller foreldre. Flere av overlegene sa at de på sin side ikke hadde hatt de samme mulighetene til å ta hensyn til hjemmesituasjonen i småbarnsfasen, som de opplevde at leger i spesialisering nå hadde:

«Når jeg var helt fersk assistentlege, så fikk vi bare høre av avdelingsoverlegen at $\mathrm{i}$ hans tid, når han var i turnus, så gikk de todelt vakt og skrev på vanlig skrivemaskin. Det skulle sitte langt inne å være hjemme med syke barn, altså.» (Gruppe 2)

Når det gjaldt normen om tilstedeværelse og utfordringene i balansen mellom jobb og hjem, var det et tydeligere skille mellom overleger og leger i spesialisering enn mellom kjønnene. Flere av overlegene hadde en partner som tok, og som hadde tatt mye 
ansvar hjemme, mens leger i spesialisering måtte ta en større del av dette ansvaret selv. Både mannlige og kvinnelige leger i spesialisering uttrykte et ønske om å prøve å balansere legejobb med fritid og familie. Noen beskrev at valget av spesialitet var preget av i hvilken grad spesialiteten var egnet til å balansere mellom jobb og hjem. En del overleger opplevde at leger $\mathrm{i}$ spesialisering tok mer hensyn til ansvar utenom arbeidsplassen ved å være hjemme med syke barn eller gå tidlig for å hente i barnehagen, og opplevde selv å bli sittende igjen med ansvaret for å få jobben gjort. På den andre siden opplevde leger i spesialisering det vanskelig å ta hensyn til hjemmesituasjonen fordi de var redde for ikke å fremstå som dedikerte nok.

Hva kan gjøres?

Det var bred enighet om at bedre planlegging fra ledelsens side kunne gjort arbeidssituasjonen mer forutsigbar og mindre stressende. Flere, både leger i spesialisering og overleger, mente at noe fravær burde det vært tatt høyde for:

«Ja, og så har ikke ressurstilgangen eller utviklingen fulgt med i tiden, så man er bemanningsmessig fortsatt der at man egentlig forventer at ingen er syke, at ingen har syke barn og man jobber en ti-tolv timer overtid $i$ uka.» (Gruppe 2)

På et sykehus ble fraværet forsøkt kompensert ved å pålegge leger i spesialisering møteplikt på sine fordypningsdager, og stipendiater måtte stille opp som vikarer i det kliniske arbeidet i sin forskningstid.

Enkelte lanserte tanken om en «livsfaseavhengig tilpasning» som kunne bedre arbeidsforholdene og styrke pasientsikkerheten. Flere overleger foreslo bedre tilretteleggelse fra ledelsens side for å få leger til å ta lederjobber.

\section{Diskusjon}

Utfordringer knyttet til idealene om å være gode sykehusleger finner vi både i legekollegiet, $\mathrm{i}$ det å lede og å bli ledet og i balansen mellom hjem og jobb. Både norske og internasjonale studier viser at mange leger går på jobb når de er syke og forventer at kollegene gjør det samme (18). Dette skyldes på den ene siden lojalitet: ikke å pålegge kollegene mer arbeid. På den annen side kan fravær true idealet om den faglig dedikerte legens utholdenhet og arbeidskapasitet. Et eksempel på dette er når yngre leger prioriterer andre livsarenaer og dermed utfordrer eldre kollegers oppfatninger av hva som er nødvendig grad av dedikasjon for en "god lege». Enkelte overlegers tydelighet på at profesjonskulturen ikke måtte være en sutrekultur, bidro til at leger i spesialisering ikke meldte fra om utfordringene de hadde med å få til en forventet grad av tilstedeværelse.
Fordi flere av legene i spesialisering opplever utfordringer med å leve opp til normene i kollegiet, og så lenge graden av profesjonalitet delvis ser ut til å bli målt ut fra antall timer man jobber, vil skillet mellom generasjonene av leger opprettholdes (9). Slike innbyrdes konflikter i legekollegiet kan bidra til at utfordringer individualiseres fordi de er vanskelige å strukturere på et organisatorisk nivå.

I dag har både mannlige og kvinnelige leger i stor grad partnere med egne karrierer, og ofte er partner også lege (19). Til tross for dette ser profesjonskulturen ut til å opprettholde forestillingen om at det å ta hensyn til egen familie ikke er forenlig med å være en «god lege». Dette samsvarer med funnene fra en studie blant allmennleger der det å fremstå som frisk var viktig fordi de opplevde at deres helsetilstand ble brukt som en indikator på deres medisinske kompetanse (20). Når det å oppleve sosial støtte fra legekollegene har vist seg å gi bedre trivsel (21), blir det å kunne bryte med denne typen forestillinger ekstra krevende.

En måte å redusere stress knyttet til balansen mellom jobb og hjem er selvsagt å redusere arbeidstiden (19), men både i Norge og internasjonalt diskuteres det om en ytterligere reduksjon i legenes arbeidstid kan senke nivået på spesialistutdanningen (22). Samtidig kan kvaliteten av helsetjenestene henge sammen med legenes trivsel (23), selv om dette er lite undersøkt i norske sykehus.

Denne studien har vist at normene om tilstedeværelse og arbeidskapasitet utfordrer ivaretakelse av egne behov, men også bidrar til å opprettholde en full stab på jobb. Når fravær er noe som blir ordnet innad i kollegiet, er det sannsynligvis lite av denne typen informasjon som når ledelsen. En forutsetning for at ledere skal kunne tilrettelegge mulighet for fravær er at de får vite om behovet. Det er diskrepans mellom legenes store grad av selvstendighet og selvledelse og en samtidig forventning om at ledelsen skal se og dekke deres behov. Dette kan føre til usikkerhet og manglende involvering fra ledelsens side i for eksempel fraværshåndtering. En svensk studie har vist at sykehusledere ofte utøver en svak, uklar og delvis fraværende lederstil overfor leger (12). Det kan settes spørsmåltegn ved om norske sykehusledere har nødvendig tillit og anerkjennelse fra legekollegiet for å lykkes med sin ledelse av leger.

Leger som jobber i norske sykehus har både klinisk og organisatorisk ansvar. Kombinasjonen av legenes mangelfulle opplæring og erfaring i ledelse (24), og at legitimiteten til en legeleder avhenger av fersk klinisk erfaring, kan gjøre lederstillinger svært krevende og lite attraktive for leger. Dette er i motsetning til sykepleiere, som nettopp gjennom administrasjon og ledelse oppnår status (25). Samtidig mener flere leger at det er avgjørende at kolleger tar lederstillinger for å bidra både med faglig kompetanse og for å kunne påvirke utformingen av legerollen i fremtidens helsevesen.

Det er et klart behov for en større anerkjennelse, både i legekollegiet og i sykehusledelsen, av at leger også har rett til fravær ved egen sykdom eller syke barn. Dette vil utfordre sykehusavdelingenes bemanning. Tydeligere ledelse kombinert med bedre gjensidig forståelse vil kunne legge til rette for strukturelle endringer som gagner både legenes arbeidsmiljø og kvalitet og sikkerhet i pasientarbeidet.

Metodisk vil vi kommentere at styrken med en kvalitativ studie er at den genererer opplevelsesbasert kunnskap i større grad enn kvantitative rangeringer (26). Den eksterne validiteten av funnene i studien er likevel opprettholdt ved at materialet inkluderer leger fra et stort sentralt og et mindre lokalt sykehus, fra ulike fagområder, og både leger i spesialisering og overleger (26).

Rekrutteringen kan ha ført til at vi fikk et utvalg av leger med spesiell interesse for temaet og med større mulighet for å jobbe lange arbeidsdager fordi intervjuene $\mathrm{i}$ stor grad var på slutten av arbeidsdagen. I fokusgrupper kan deltagerne påvirke hverandre slik at det blir en større konsensuseffekt enn man kanskje ville fått ved individuelle intervjuer (26). Det at moderatorene i intervjuene var leger kan på den ene siden ha fremmet forståelse og gjenkjenning av det som beskrives, men innebærer på den annen siden en risiko for at enkelte legespesifikke faktorer, er blitt tatt for gitt og ikke blitt eksplisitt uttrykt.

Vi har under analysen sett etter variasjoner rundt hovedtemaene for å styrke den interne validiteten av funnene. Funnene er presentert og diskutert i ulike kliniske og forskerfora, og deltagerne har fått muligheten til å lese gjennom resultatene og godkjenne bruken av sitater.

Resultatene i studien peker på noen mulige implikasjoner og forslag til tiltak der flere aktører kan ta ansvar. Legeforeningen kan fremme en diskusjon om balansen mellom faglig dedikasjon og ivaretakelse av egne behov som et tema i de ulike spesialistutdanningene og på lederkursene, slik at det blir en naturlig del av identitetsutviklingen som lege. I tillegg til de rådgivende tilbudene som finnes for enkeltleger via Støttekollegaordningen (27) og Villa Sana (28), er det viktig å sette leger bedre i stand til å ivareta egne behov på et individuelt og et kollegialt nivå.

Sykehuslegene kan selv bidra til å skape større rom for å reflektere høyt i kollegiet rundt utfordringen ved å skulle være en fag- 
lig dedikert lege som samtidig ivaretar egne behov. Aksept blant kolleger og bedret gjensidig kunnskap mellom leger og ledelse om den andre parts verdier og ansvarsområder, vil være viktige premisser for å kunne gjøre strukturelle endringer, for eksempel en livsfasetilpasning av jobben som sykehuslege. For å oppnå endring vil det være viktig at de som sitter med ansvaret for organiseringen av helsevesenet på ulike nivåer, legger til rette for å muliggjøre prosesser som beskrevet ovenfor.

\section{Konklusjon}

Forventninger om faglig dedikasjon, sammen med retningsgivende normer om tilstedeværelse, utholdenhet og hardt arbeid, får konsekvenser for legekollegiet, forholdet til ledelsen og håndteringen av balansen mellom jobb og hjem.

Studien viser at det er viktig at profesjonen reflekterer over hva som kan være godt nok, fordi en slik norm vil være nødvendig for å kunne ivareta hensyn til egne behov. Det er imidlertid en kompleks og krevende balanse å få til, fordi behovene er motstridende. Hvordan balansen skal håndteres på gruppenivå og individnivå, er spørsmål det er viktig å diskutere.

Vi takker leger som har deltatt i intervjuer, og som har hjulpet oss med informasjonsmøter og tilrettelegging i forkant.

\section{Tuva Kolstad Hertzberg (f. 1973)}

er lege i spesialisering i psykiatri og stipendiat. Forfatter har fylt ut ICMJE-skjemaet og oppgir ingen interessekonflikter.

\section{Helge Skirbekk (f. 1971)}

er medisinsk sosiolog med doktorgrad om pasienters tillit til leger. Han er førsteamanuensis og redaktør av antologien Tillit i Norge. Forfatter har fylt ut ICMJE-skjemaet og oppgir ingen interessekonflikter.

\section{Reidar Tyssen (f.1955)}

er spesialist i psykiatri, dr.med., professor i medisinske atferdsfag og avdelingsleder. Forfatter har fylt ut ICMJE-skjemaet og oppgir ingen interessekonflikter.

\section{Olaf Gjerløw Aasland (f. 1944)}

er lege og seniorforsker.

Forfatter har fylt ut ICMJE-skjemaet og oppgir ingen interessekonflikter.

\section{Karin Isaksson Rø (f. 1962)}

er spesialist i arbeidsmedisin, ph.d., instituttleder og overlege og har en mastergrad i helseadministrasjon og ledelse (MHA).

Forfatter har fylt ut ICMJE-skjemaet og oppgir ingen interessekonflikter.

\section{Litteratur}

1. Hertzberg TK, Skirbekk H, Tyssen R et al. Den gode legen - sterk og utholdende. Tidsskr Nor Legeforen 2016; 136: 1631-4.

2. Hertzberg TK, Rø KI Vaglum PJ et al. Work-home interface stress: an important predictor of emotional exhaustion 15 years into a medical career. Ind Health 2016; 54: 139-48.

3. Aasland OG, Rosta J. Hvordan har overlegene det. Overlegen 2011: 1: 47-55.

4. Kivimäki M, Sutinen R, Elovainio $M$ et al. Sickness absence in hospital physicians: 2 year follow up study on determinants. Occup Environ Med 2001: 58: $361-6$.

5. Irvine $\mathrm{DH}$. Everyone is entitled to a good doctor Med J Aust 2007; 186: 256-61

6. Tyssen R, Vaglum P, Grønvold NT et al. The relative importance of individual and organizational factors for the prevention of job stress during internship: a nationwide and prospective study. Med Teach 2005; 27: 726-31

7. West CP. Dyrbye LN, Rabatin JT et al. Intervention to promote physician well-being, job satisfaction, and professionalism: a randomized clinical trial. JAMA Intern Med 2014; 174: 527-33.

8. Beran TN, Kaba A, Caird J et al. The good and bad of group conformity: a call for a new programme of research in medical education. Med Educ 2014: 48: 851-9.

9. Smith LG. Medical professionalism and the generation gap. Am J Med 2005; 118: 439-42.

10. Heldal F. Kald krig på norske sykehus. Dagens Næringsliv 17.2.2016.

11. Skirbekk H, Nortvedt P. Making a difference: a qualitative study on care and priority setting in health care. Health Care Anal 2011; 19: 77-88.

12. Knorring MV. The manager role in relation to the medical profession. Doktoravhandling. Stockholm: Department of clinical neuroscience, Karolinska Institutet, 2012.

13. Gjerberg E, Sørensen BA. Enhetlig ledelse i sykehus. Oslo: Arbeidsforskningsinstituttet, 2006.

14. Frich JC, Gran SF, Vandvik PO et al. Kunnskap, ledelse og kvalitet i studiet. Tidsskr Nor Legeforen 2012; 132: 1768-70

15. Orvik A. Den dobbelte kompetansen. I: Orvik A, red. Organisatorisk kompetanse : Innføring i profesjonskunnskap og klinisk ledelse. 2. utgave. Oslo: Cappelen Damm akademisk, 2015: 17-39

16. Malterud K. Systematic text condensation: a strategy for qualitative analysis. Scand J Public Health 2012: 40: 795-805.
17. Tjora A. Analyse av kvalitative data. I: Tjora A, red. Kvalitative forskningsmetoder i praksis. 2 utgave. Oslo: Gyldendal Akademisk, 2012: 174-95.

18. Gustafsson Sendén M, Løvseth LT, Schenck-Gustafsson $\mathrm{K}$ et al. What makes physicians go to work while sick: a comparative study of sickness presenteeism in four European countries (HOUPE). Swiss Med Wkly 2013; 143: w13840.

19. Røvik JO, Tyssen R, Hem E et al. Job stress in young physicians with an emphasis on the workhome interface: a nine-year, nationwide and longitudinal study of its course and predictors. Ind Health 2007; 45: 662-71

20. Thompson WT, Cupples ME, Sibbett CH et al. Challenge of culture, conscience, and contract to general practitioners' care of their own health: qualitative study. BMJ 2001; 323: 728-31.

21. Hoff T, Whitcomb WF, Nelson JR. Thriving and surviving in a new medical career: the case of hospitalist physicians. J Health Soc Behav 2002; 43 72-91.

22. Rosta J, Aasland OG. Weekly working hours for Norwegian hospital doctors since 1994 with special attention to postgraduate training, work-home balance and the European working time directive: a panel study. BMJ Open 2014: 4: e005704.

23. Wallace JE, Lemaire JB, Ghali WA. Physician wellness: a missing quality indicator. Lancet $2009 ; 374$ $1714-21$

24. Bååthe F, Norbäck LE. Engaging physicians in organisational improvement work. J Health Organ Manag 2013; 27: 479-97.

25. Torjesen DO. Kunnskap, profesjoner og ledelse. Tidsskr Samfunnsforsk 2007; 48: 275-90.

26. Malterud K. Metodeutfordringer. I: Malterud K, red. Fokusgrupper som forskningsmetode for medisin og helsefag. Oslo: Universitetsforlaget 2012: $131-5$

27. Isaksson Rø K, Aasland OG. Støttelegers syn på støttekollegaordningen. Tidsskr Nor Legeforen 2016: 136: 313-6.

28. Isaksson Rø K, Gude T, Tyssen R et al. Counselling for burnout in Norwegian doctors: one year cohor study. BMJ 2008; 337: a2004.

Mottatt 20.1. 2016, første revisjon innsendt 22.5 2016, godkjent 12.8. 2016. Redaktør: Tor Rosness. 